\title{
Effect of Spraying Dormex and Sitofex and Time of Application on Date of Bud Burst Fruit Set, Yield and Fruit Characteristics of "Costata" Kaki Cultivar
}

\author{
Naguib, S.G. ${ }^{1}$;W.M.Abd El-Messeih ${ }^{2}$;E.S.Attala ${ }^{1}$ and S.A.Asaad ${ }^{1}$
}

\begin{abstract}
This present work was carried out to investigate the effect of spraying Dormex (at 3\%) at the end of Jan. and Sitofex at $(5,10,15$ and $20 \mathrm{ppm})$ at full bloom and fruit set alone or combined with each other on time of bud burst, fruit set \%, yield/tree and fruit quality of "Costata" kaki cultivar, planted in El-khadra area El-Bohira Governorate. The results can be summarized in the following points:

1- In both years of study, the date of bud burst of trees sprayed with Dormex (at 3\%) was early (28//2/2007 and27/2/2008) than that of control trees $(19 / 3 / 2007$ and $21 / 3 / 2008$ ), respectively.

2- Insignificant differences were detected between the two tested dates of spraying Sitofex at $(5,10,15$ and $20 \mathrm{ppm})$ for all the studied parameters.

3- The best effects were obtained from trees sprayed with 20 ppm sitofex + dormex at $3 \%$ treatment, so it is recommended to obtain high fruit set percentage, fruit yield and to improve physical fruit properties i.e: weight size,length,diameter and firmness. On the other side,this treatment induced low TSS\%, high acidity \% and tannins \%, that means delaying the date of maturation which has great importance for postponing harvest date and increasing shelf-life period and storage ability.
\end{abstract}

\section{INTRODUCTION}

The oriental persimmon (Diospyros kaki L, Fam Ebenaceae) is one of the deciduous fruit that native to China, where it has been cultivated for centuries and more than two thousands different cultivars exist. It spread to Korea and Japan many years ago where additional cultivars were developed. Persimmon tree has been introduced to Egypt in 1911 by Ministry of Agriculture (Baghdady and Minessy, 1964). Recently, cultivation of oriental persimmons, (Diospyros Kaki L,) is extended in Egypt.

Good yield and high fruit quality are two important targets of fruit growers' adivites. There are several approaches to increase productivity and fruit quality of fruit trees, it is well known that plant growth regulators have been used successfully as an applicable mean for enhancing flowering, fruiting and improving fruit quality of persimmon tree.

\footnotetext{
${ }^{1}$ Horticultural Research Insititue, Agricultural Research Center, Egypt.

${ }^{2}$ Nubaria Hort. Res. Station Hort. Res. Inst., Agric Res. Center, Egypt.

Received February28, 2010, Accepted March22, 2010
}

It is documented that fruit size depends on different factors:

1- The number of cells presented at fruit set.

2- Number of cells division that occur subsequently.

3- The extent which these cells expand.

Cell division in the early stage of fruit development has a major influence on final fruit size (Westwood, 1988). Early fruit cell division normally is influenced by natural growth hormones especially cytokinin (Looney, 1993). The new plant growth regulator CPPU in many studies has indicated that it is one of the major factors affecting fruit growth and fruit size. On grapes (Nickell, 1986); on apple (Greene, 1989); on kiwi fruit (Baisl, et al 1999 and Lows and Woolley, 1992); on pear (Guirguis et al, 2003) on persimmon (Ital et al, 1995, and Sugiyam et al, 1995).

In Egypt, the high drop of kaki fruits before maturity is the major problem for persimmon production, so the final yield is very low. Our aim of this investigation is to increase the crop and improve the fruit quality through plant growth regulator CPPU*in many studies has indicated that it is one of the major factors affecting fruit growth and fruit size. On grapes (Nickell, 1986); on apple (Greene, 1989); Kiwi fruit (Baisl, et al 1999 and Lows and Wolley, 1992); on pear (Girguis et al, 2003) on persimmon (Jtal et al, 1995, and Sugiyam et al, 1995).

In Egypt, the high drop of kaki fruits before maturity is the major problem for persimmon production, so the final yield is very low. The aim of this investigation is to increase the crop and to improve the fruit quality through following the effect of spraying Dormex and CPPU*(Sitofex) alone and the combination between them on date of bud burst, fruit set\%, yield and fruit quality of "Costata" kaki trees.

\section{MATERIALS AND METHODS}

This study was conducted at El-khadra area, ElBohira Governorate, during two successive seasons (2006-2007) and (2007-2008) on 7 years old "Costata" persimmons trees (Diospyros kaki L.Fam: Ebenaceace) budded on Virginiana rootstook and planted in clay soil. 
The 16 selected trees were spaced at $4 \times 4 \mathrm{~m}$. apart,healthy, similar in their vigor,as possible, and treated with normal agriculture practices. The target of this work is to study the effect of Dormex (at 3\%) and CPPU(Sitofex)(at 5, 10, 15 and 20ppm)spraying and their combination on the date of bud burst, fruit set \%, yield and fruit quality. Tested trees (except the 2 control trees) were sprayed with Dormex (at3\%)on 27and29 January in the two studied years, respectively.Fourteen trees were divided into 2 groups,one was sprayed with CPPU (at 5,10,15 and 20ppm)at full bloom $\left(\mathrm{A}_{1}\right)$, the other was sprayed with $\mathrm{CPPU}^{\dagger}$ (the same concentration) at fruit set, while control trees were sprayed with tap water.

Four main branches as uniform as possible were chosen at the four cardinal points of each studied tree. Tagged and sprayed with one of the four concentrations of Sitofex at $A_{1}$ and $A_{2}$ as mentioned before, while Dormex (at3\%) was sprayed on whole studied trees. Thus, studied treatments with each of $A_{1}$ and $A_{2}$ were as follows:

1-Control

2-Dormex

3-CPPU (Sitofex) at5ppm.

$4-\ldots \ldots \ldots \ldots \ldots \ldots \ldots \ldots+$ Dormex.

$5-\ldots \ldots \ldots \ldots \ldots$ at $10 \mathrm{ppm}$

6-CPPU (Sitofex) at10ppm +Dormex.

$7-\ldots \ldots \ldots \ldots \ldots$ at $15 \mathrm{ppm}$

$8-\ldots \ldots \ldots \ldots \ldots \ldots \ldots . . . . . . .+$ Dormex.

$9-\ldots \ldots \ldots \ldots \ldots \ldots$ at $20 \mathrm{ppm}$..

$10-\ldots \ldots \ldots \ldots \ldots \ldots \ldots \ldots .+$ Dormex.

The experimental treatments were arranged in a complete randomize block design.

The studied parameters were the following:

\section{- Date of bud burst:}

Date of budburst was recorded in the two studied seasons.

\section{- Fruit set percentage:}

The total number of flowers on each tagged branch was counted at full bloom. The number of set fruit on the same branches was recorded after 4 weeks from full bloom.

The fruit set percentage was calculated according to the following equation:

\footnotetext{
* CPPU(sitofex) (synthetic cytokinin) N-(2-chloro-4-pyridinyl) sheujlcurea is a product of ALZ. Chem. Germany. Trans Fridge Wt., Camp.
}

Fruit set $\%=$ [number of developing fruitlets/total number of flowers] x100. (Westwood, 1988).

\section{- Fruit yield /tree:}

Fruit yield per tree $(\mathrm{kg})$ was determined at fruit maturity stage (according to Westwood, 1988).

\section{- Fruit quality:}

Samples of 10 fruit for each replicate at harvest time were taken when fruits of the control trees attained maturity (according to El- Azzouni et al,1975)to determine fruit weight,sze,length, diameter and fruit firmness. Percentage of total soluble solids (TSS\%); acidity $\%$ as malic acid in fruit juice were determined according to (AOAC,1985) and tannins content\% was recorded.

The obtained data were subjected to analysis of variance and the means were compared using the new LSD values at 0.05 (according to Sendecor \&Cochran, 1990).

\section{RESULTS}

\section{Date of bud burst:}

The date of bud burst of sprayed trees with Dormex $3 \%$ was $28 / 2$ in 2007 and $27 / 2$ in 2008; meanwhile it was 19/3 in 2007 and 21/3 in 2008 for the control trees.

\section{Fruit set\%:}

Effect of date of spray on final fruit set\% was statistically insignificant (Table, 1). As for the effect of the treatments, all the applied treatments significantly increased final fruit set\% compared with the control which recorded the lowest percentage. Spraying Dormex $(3 \%)+$ Sitofex $(20 \mathrm{ppm})$ and Dormex $(3 \%)+$ Sitofex $(15 \mathrm{ppm})$ treatments recorded the highest percentages .

The interaction between date of spray and treatments was significant. Data revealed that the highest percentage was obtained as a result of Dormex (3\%) + Sitofex $(20 \mathrm{ppm})$ spraying either at full bloom or at fruit set for both seasons.

\section{Yield / Tree:}

Effect of date of spray on the yield was statistically insignificant (Table,1). Yield was significantly increased by treatments application. Spraying Dormex (3\%) + Sitofex $(20 \mathrm{ppm})$ resulted in the highest values of tree yield for both seasons respectively, no significant differences could be shown between the two treatments Dormex $(3 \%)+$ Sitofex $(20 \mathrm{ppm})$ and Dormex $(3 \%)+$ Sitofex $(15 \mathrm{ppm})$ treatments in both seasons. The interaction between date of spray and treatments was significant. Data revealed that the highest yield was obtained as a result of Dormex (3\%) + Sitofex (20 ppm) treatment either at full bloom or at fruit set for both seasons. 


\section{Fruit physical characteristics:}

Effect of date of spray on fruit physical characteristics i.e. weight, size, length, diameter and firmness were statistically insignificant. Positive effects attributed to treatments applications were evident on all fruit physical characteristics (Table2). Applied treatments were superior to control. Dormex (3\%) + Sitofex $(20 \mathrm{ppm})$ treatment induced the highest effects but they were insignificantly different from Dormex $(3 \%)+$ Sitofex $(15 \mathrm{ppm})$ treatment for all studied characters. The interaction between date of spray and treatments was significant. In general, the application of
Dormex (3\%) + Sitofex (20 ppm) spraying either at full bloom or at fruit set for both seasons (Figure,1-5) gave the highest values of fruit physical parameters.

\section{Fruit chemical characteristics:}

Fruit chemical characteristics i.e. TSS\%, acidity\% and tannins $\%$ were tabulated in (Table 3 ). Insignificant differences were detected between the two tested dates. With respect to spraying, all applicated treatments resulted in differences in TSS\%, acidity $\%$ and tannins $\%$ compared with control. Spraying Dormex (3\%) + Sitofex $(20 \mathrm{ppm})$ resulted in the lowest percentage of

Table 1. Effect of the experimental treatmets on the\% final fruit set and yield (kg) of Kaki trees

\begin{tabular}{|c|c|c|c|c|c|}
\hline & \multicolumn{2}{|c|}{ Final fruit set \% } & \multicolumn{2}{|c|}{ Yield / Tree (kg) } \\
\hline & & 1st season & 2nd season & 1st season & 2nd season \\
\hline \multirow{3}{*}{$\begin{array}{l}\text { (A): Date of } \\
\text { spray }\end{array}$} & (A1) Full bloom & 62.36 & 58.03 & 36.27 & 34.05 \\
\hline & (A2) Fruit set & 65.30 & 60.24 & 36.31 & 32.78 \\
\hline & new L.S.D. (A) & N.S & N.S & N.S & N.S \\
\hline \multirow{11}{*}{$\begin{array}{c}(\mathrm{B}): \\
\text { Treatment }\end{array}$} & (B1) Control & 53.60 & 50.40 & 28.40 & 26.80 \\
\hline & (B2) Dormex & 56.10 & 51.95 & 30.20 & 29.20 \\
\hline & (B3) 5ppm Sitofex & 59.60 & 54.55 & 32.00 & 30.15 \\
\hline & (B4) Dormex + 5ppm Sitofex & 60.65 & 55.50 & 33.15 & 30.85 \\
\hline & (B5) 10ppm Sitofex & 63.05 & 59.45 & 35.15 & 31.50 \\
\hline & (B6) Dormex + 10ppm Sitofex & 64.45 & 60.50 & 36.50 & 33.95 \\
\hline & (B7) $15 \mathrm{ppm}$ Sitofex & 67.00 & 62.10 & 38.60 & 35.65 \\
\hline & (B8) Dormex + 15ppm Sitofex & 68.00 & 62.80 & 40.90 & 36.55 \\
\hline & (B9) 20ppm Sitofex & 71.85 & 66.05 & 43.25 & 39.00 \\
\hline & (B10) Dormex + 20ppm Sitofex & 74.00 & 68.05 & 44.75 & 40.50 \\
\hline & new L.S.D. (B) & 4.37 & 4.93 & 1.68 & 2.03 \\
\hline \multirow{21}{*}{$\begin{array}{l}(\mathrm{AXB}): \\
\text { Interaction }\end{array}$} & B1 & 53.60 & 50.40 & 28.40 & 26.80 \\
\hline & $\mathrm{B} 2$ & 55.80 & 51.40 & 30.60 & 29.60 \\
\hline & B3 & 58.60 & 52.50 & 32.40 & 30.50 \\
\hline & B4 & 59.80 & 54.60 & 33.50 & 31.40 \\
\hline & B5 & 62.40 & 58.60 & 35.60 & 32.40 \\
\hline & B6 & 63.30 & 59.40 & 36.80 & 34.60 \\
\hline & B7 & 65.60 & 61.60 & 38.40 & 36.80 \\
\hline & $\mathrm{B} 8$ & 65.50 & 61.80 & 39.60 & 37.40 \\
\hline & B9 & 68.40 & 64.40 & 42.80 & 39.60 \\
\hline & $\mathrm{B} 10$ & 70.60 & 65.60 & 44.60 & 41.40 \\
\hline & B1 & 53.60 & 50.40 & 28.40 & 26.80 \\
\hline & $\mathrm{B} 2$ & 56.40 & 52.50 & 29.80 & 28.80 \\
\hline & B3 & 60.60 & 56.60 & 31.60 & 29.80 \\
\hline & B4 & 61.50 & 56.40 & 32.80 & 30.30 \\
\hline & B5 & 63.70 & 60.30 & 34.70 & 30.60 \\
\hline & B6 & 65.60 & 61.60 & 36.20 & 33.30 \\
\hline & B7 & 68.40 & 62.60 & 38.80 & 34.50 \\
\hline & B8 & 70.50 & 63.80 & 42.20 & 35.70 \\
\hline & B9 & 75.30 & 67.70 & 43.70 & 38.40 \\
\hline & B10 & 77.40 & 70.50 & 44.90 & 39.60 \\
\hline & new L.S.D. (AXB) & 6.47 & 7.13 & 2.39 & 2.77 \\
\hline
\end{tabular}


TSS and the highest percentage of acidity and tannins for both seasons, no significant differences could be shown between the two treatments Dormex (3\%)+ Sitofex (20 ppm) and Dormex (3\%) + Sitofex (15 ppm) treatments. The interaction between date of spray and treatments was significant. Data revealed that the lowest percentage of TSS and the highest percentage of acidity and tannins were obtained as a result of Dormex (3\%) + Sitofex (20 ppm) and Dormex (3\%) + Sitofex (15 ppm) treatments either at full bloom or at fruit set for both seasons (Figures, 6, $7 \& 8$ ).

\section{DISCUSSIONS}

The obtained data revealed that spraying Dormex $3 \%$ advanced budburst by 20days and 23days as compared with the control trees in 2007and 2008 ,respectively. Many investigators supported these findings. Hsing and Chin, 1989 reported that hydrogen cyanamide (3\%) application was effective in inducing bud sprouting of "Syhjou" persimmon. Mokhtar et at, 1994 mentioned that Asian pear showed advanced budburst due to cyanamide hydrogen. The same finding were reported by Marwad et al,1998 on persimmon trees.. The data showed the effectiveness of the different applications of CPPU or Dormex alone or the combination between the two materials on kaki fruits are confirmed by the findings of (Lows and Wolley 1992).

CPPU has a positive effect on decreasing fruit drop percentage and significantly increasing initial fruit set and fruiting, fruit weight, size, length, diameter and fruit shape index, all these findings are in agreement in this aspect with those of (Girguis et al, 2003, Lows and Wolley 1992, Biasl at al, 1991, Nickell, 1986 and Devlin and Koszauski, 1988).

CPPU has proven to be highly effective in stimulating growth of such fruit species (grape, apple, cranberry, kaki, pear and persimmon.).

The material CPPU (cytokinin-like effect) is a synthetic plant growth regulator, it accelerates early cell division in the fruitlet and also subsequent cell division or it does through changing natural known activity, it has been shown that CPPU application to kaki fruit shortly after fruit set stimulated cell division and hence also established a potential for greater subsequent fruit expression. This potential is realized when the high metabolism of the increased cell number attracts greater amount of assimilates (water, minerals and carbohydrates) gets bigger size because it has enough cells that enabled the fruit to expand to a large size (Lows and Wolley 1992 and Biasl at al, 1991). Hence, it is clear that the present results are in agreement with the previous findings.

\section{CONCLUSION}

Two years of study on the effect of Dormex and Sitofex on persimmon fruit, indicated CPPU's effectiveness and suggested it's suitability as a tool for inducing a significant improvement in kaki cropping. The use of CPPU compound opens the door widely as a new opportunity managing kaki fruit production. Data revealed that the best treatment was spraying with Dormex $(3 \%)+$ Sitofex (20 ppm).

\section{REFERENCES}

Association of Official Agricultural Chemistry (1985): Official Methods of Analysis (A.O.A.C.) pp. 490-510. $14^{\text {th }}$ ed., Benjam in Froukliv Station,Washington D. C., U.S.A.

Baghdady, H. A. and F. Minessy (1964): The fruit production. Text book, Dar El-Maarif, Egypt. P. 563.

Biasl, R.; Costa, G.; Glulioui, R.; Succi, F. and Sousavini, S. (1991): Effect of CPPU on kaki fruit performance, Acta Horticulturae, 297, 367-373.

Devlin, R.M., and Koszoaiski, Z.K., (1988): Effect of CPPU on yield and development of "Early Black" cranberry. Proc. of the plant growth regulator, Society of America, 136-140.

El-Azzoumi, M.M.; Abd El-Latif, F.I. and Kenawi, E.A. (1975): Determination of maturity in pear cultivars LeCont, Shoubra and Pin-apple. Arch. Gartenban. 23 (8): 483-489.

Greene, D.W. (1989): CPPU influences "McIntosh" apple crop load and fruit characteristics, Hort. Science, 24: 9496.

Girguis, N.S.; Eman S. Attala and Ali, M.M. (2003): Effect of Sitofex (CPPU) on fruit set, fruit quality of Le-Conte pear cultivar. Annals of Agric. Sci. Moshtohor. 41(1): 271-282.

Helial, B.M. (1986): Physiological response of young LeConte pear trees to some cultural and growth regulators treatment. Ph.D. Thesis. Fac. Of Agric., Moshtohor, Zagazig univ. (after kabil).

Hsing-Sun Chang and Chin-Ho Lin.1989. The application of cyanamide for termination of dormancy in"Syhjou" persimmon with in vitro cutting test and in field test.Gar.,54(1).S.30-33,ISSN 0016-478x.

Ital, A.; Tanabe, K.; Tamura, F.; Susaki, S.; Yonemori, K. and Sugiura, A. (1995): Synthetic cytokinis control persimmon fruit shape, size and quality. Journal of Horticultural Science, 70: 867-873.

Looney, N.E. (1993): Improving fruit size, appearance and other aspects of fruit crop "quality" with plant bioregulating chemicals. Acta-Horticulturae, 329: 120127.

Lows, G.S. and Woolley, D.J. (1992): A new way to grow bigger kiwi fruit. Department of plant Science, Morsey University, April. The orchardist pp. 35:77. 
Marwad,I.A.; E.M.El-Fakharani and I.H. Osman.1998.Effect of some hydrogen cyanamide treatments on behavior, yield, fruit quality and shoot growth of costata persimmon trees.Egypt.J.Appl.Sci;13 (8).

Mokhtar, H.; E.M. El-Fakharani and R.G.Stino.1994.Effect of hydrogen cyanamide on flowering, yield and fruit quality of some Asian pear cultivars grown in Egypt. Egypt.,J. Appl.Sci.9(3):159-170.
Nickell, L.G. (1986): Effect of N-(2-chloro-1-pyridimet)-N phenyl urea on grapes and other crops. Proc. of the plant growth regulator, Society of America, 13: 236-241.

Snedecor, G. W. and Cochran, W.G. (1980): Statistical Methods. 6th ed, Iowa State Univ. Press. U.S.A., pp. 50.

Sugiyam N., Yamaki, Y.T. (1995): Effects of CPPU on fruit set and fruit growth in Japanese persimmon. Scientia Horticulturae, 60: 337-343.

Westwood, M.N. (1988): Temperate zone pomology. Physiology and culture. Timber Press, Portland, Oregon. 


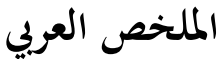

تأثير الرش بالدوركس والسيتوفكس ومواعيد الإضافة على ميعاد تفتح البراعم ونسبة العقد والمحصول وصفات الثمار للكاكى صنف "كوستاتا"

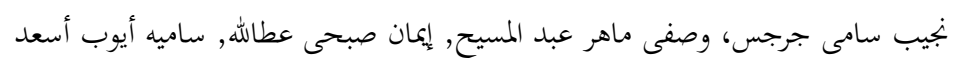

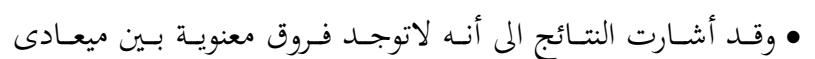

الإضافة تتسيتوفكس بالنسبة لجميع الصفات المدروسة.

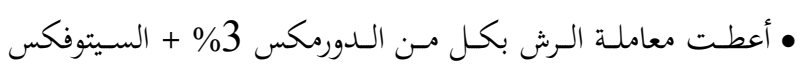

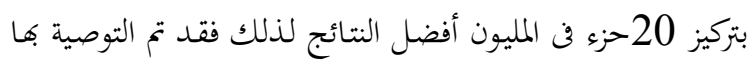

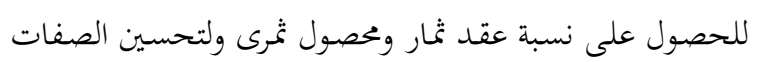

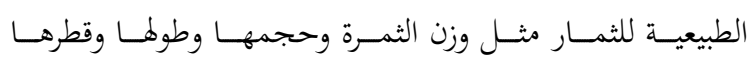

$$
\text { وصلابتها. }
$$

• على الجانب الآخر فإن (نسبة المواد الصلبة الذائبة الاقل والحموضة

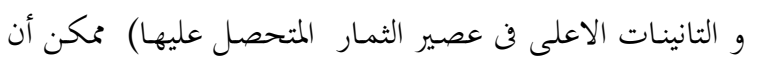

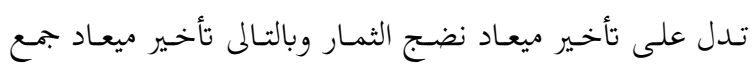
الثمار وزيادة عمر الثمرة التسويقى وقابليتها للتخزين.

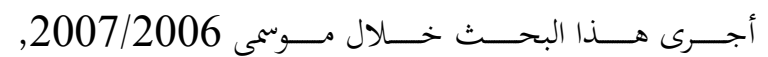

2008/2007 لدراسة تأثير الرش بكل من الدورمكس بتركيز 3

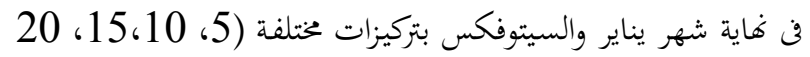

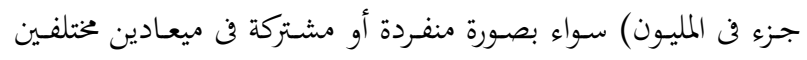

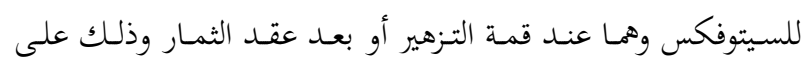

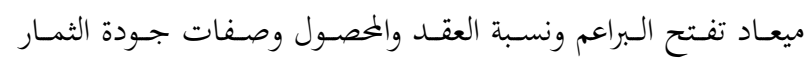

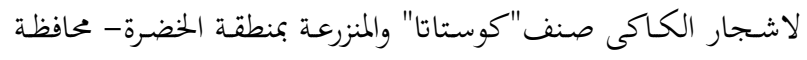

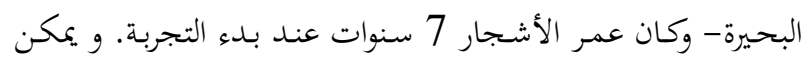
تلخيص النتائج المتحصل عليها فيما يلى:

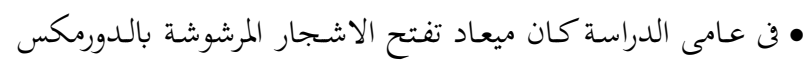

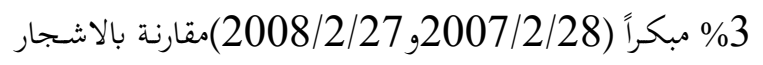
الكنترول (2007/3/19 , 2008/3/21). 